Article

\title{
Study of Water Productivity of Industrial Hemp under Hot and Dry Conditions in Brandenburg (Germany) in the Year 2018
}

\author{
Katrin Drastig *(D), Inken Flemming, Hans-Jörg Gusovius $(\mathbb{D}$ and Werner B. Herppich $(\mathbb{0}$ \\ Leibniz Institute of Agricultural Engineering and Bioeconomy e.V. (ATB) Max-Eyth-Allee 100, \\ 14469 Potsdam, Germany; inkenflemming@t-online.de (I.F.); hjgusovius@atb-potsdam.de (H.-J.G.); \\ wherppich@atb-potsdam.de (W.B.H.) \\ * Correspondence: kdrastig@atb-potsdam.de; Tel.: +49-(0)331-5699-218
}

Received: 28 September 2020; Accepted: 21 October 2020; Published: 24 October 2020 updates

\begin{abstract}
Hemp (Cannabis sativa L.) is a high-yielding multi-purpose crop, but its hydrological functioning is poorly understood. Studies on the interception processes in hemp have been lacking so far. This study contributes to the understanding of the influences of evaporation of intercepted water and other hydrological fluxes within plants of two cultivars, "Santhica 27" and "Ivory", on the water productivity. To determine water productivity and evaporation from interception, field measurements were conducted on plants of both cultivars at different stages of development. Precipitation $(P)$, throughfall $(T F)$, transpiration $(T)$, and volumetric water content $(V W C)$ were measured along with leaf area index ( $L A I)$ and yield of selected plant components. For the entire vegetation period, the cumulative $P$ of $44 \mathrm{~mm}$ was converted into $13 \mathrm{~mm} \mathrm{TF} \mathrm{(30 \% ).} \mathrm{The} \mathrm{inferred} \mathrm{evaporation} \mathrm{of}$ intercepted water $(I)$ was high at $31 \mathrm{~mm}(71 \%)$. For the assessment water fluxes, the evaporation of intercepted water must be considered in the decision-making process. Besides the $L A I$, the plant architecture and the meteorological conditions during the cropping cycle seem to be the main factors determining $I$ in the case of plants of both cultivars. Water productivity $\left(W P_{D M}\right)$ of the whole plant varied between $3.07 \mathrm{~kg} \mathrm{~m}^{-3}$ for Ivory and 3.49 for Santhica 27. In the case of bast yield, $W P_{D M}$ was $0.39 \mathrm{~kg} \mathrm{~m}^{-3}$ for Santhica 27 and $0.45 \mathrm{~kg} \mathrm{~m}^{-3}$ for Ivory. After the propagation of the uncertainties, the bandwidth of the $W P_{D M}$ of the whole plant was between $0.42 \mathrm{~kg} \mathrm{~m}^{-3}$ and $2.57 \mathrm{~kg} \mathrm{~m}^{-3}$. For bast fiber a bandwidth of the WP between $0.06 \mathrm{~kg} \mathrm{~m}^{-3}$ and $0.33 \mathrm{~kg} \mathrm{~m}^{-3}$ was calculated. The results show furthermore that even with a precise examination of water productivity, a high bandwidth of local values is revealed on different cultivars. However, generic WP values for fiber crops are not attainable.
\end{abstract}

Keywords: farm management practices; rainwater productivity; rainfall interception; leaf area index; plot scale

\section{Introduction}

The pressures of climate change and natural resource scarcity have fueled interest in bio-economically sustainable agronomy that requires, for example, efficient use of water. A range of focused studies have indicated that hemp (Cannabis sativa L.) may be a suitable crop for bio-economy [1-3]. China is the largest producer of hemp fibers for the textile industry [4-6]. In Germany, the cultivation of hemp was impeded by the Narcotics Law up to 1996. Although once an important crop for producing fibers, hemp acreage declined in the last century and was displaced largely by cotton and synthetic fibers. Problems accompanying cotton production are the intensive use of pesticides, soil salinization, and the high water demand of the crops [7], which is recorded as being between 763 and $915 \mathrm{~mm}$ of water (rainfall and/or irrigation) per vegetation period [8]. 
In contrast with this, hemp is a high-yielding, multi-purpose crop that at least requires no pesticides and displays limited demands with respect to fertilizer usage and crop rotation [9-11]. Hemp grown in the UK requires less water than cotton [12]. In general, hemp cultivation is described as having a positive impact on the environment $[7,13]$. Little attention has been paid to understanding the physiological basis of this high resource-use efficiency of hemp [14].

According to [15], the water productivity (WP) of industrial hemp at $0.80 \pm 0.74 \mathrm{~kg} \mathrm{~m}^{-3}$ is three times higher than that of cotton. WP refers to the ratio of output generated to water consumed and offers a conceptual framework that can be defined using different terms for the numerator (e.g., biomass, harvestable yield, economic value) and denominator (e.g., transpiration, evapotranspiration, irrigation, water inflows) [16].

Self-thinning of hemp is an important aspect for assessing the proper plant density of the crop [9]. A higher plant density is associated with high rainfall interception, which reduces the available soil water. The water productivity of a water-sensitive cultivar could be lower, because the yield is reduced or the application of additional irrigation water is required. Partly due to sexual dimorphism, there is a large heterogeneity in the crop, which may limit yields, may reduce the efficiency of resource use, and may result in variable quality [9]. This heterogeneity may also lead to a varying density of plants, which, in turn, affects the amount of water reaching the soil as throughfall.

So far, no studies have investigated the evaporation of intercepted rainwater and irrigation interception by a hemp population in detail, and this factor is often overlooked in hydrological modeling of crops in general [17]. The authors tested various existing crop canopy rainfall interception models for a wheat and a corn system. With this new contribution for hydrologists, the authors laid the foundations for further research on interception processes. For irrigation planning and water use, studies of the evaporation of intercepted water must be considered [18]. To date, evaporation of intercepted water is considered with varying degrees of precision in irrigation planning and water use studies. In Germany, only one modeling tool for supporting irrigation scheduling in crop production includes interception [19].

This study aimed to contribute to the understanding of the influence of the evaporation of intercepted water and other hydrological fluxes on the water productivity within two cultivars of hemp. The objectives of this study are (1) to present variations of transpiration, throughfall, evaporation of intercepted water, and soil moisture, which were respectively measured throughout the whole growth of plants of two hemp cultivars; (2) to model transpiration using calculated basal crop coefficients and LAI (leaf area index) for two hemp cultivars based on actual measurement of transpiration and LAI; (3) to calculate and analyze the water productivity of two hemp cultivars in the year 2018.

\section{Materials and Methods}

\subsection{Experimental Site}

Data were compiled at the research site "Marquardt Fieldlab for Digital Agriculture" of the Leibniz Institute for Agricultural Engineering and Bioeconomy (ATB). The research site $\left(52^{\circ} 28^{\prime} 2^{\prime \prime} \mathrm{N}, 12^{\circ} 57^{\prime} 39^{\prime \prime}\right.$ E) close to Potsdam (Brandenburg, Germany) is located at a height of $42 \mathrm{~m}$ above sea level (Figure 1). 


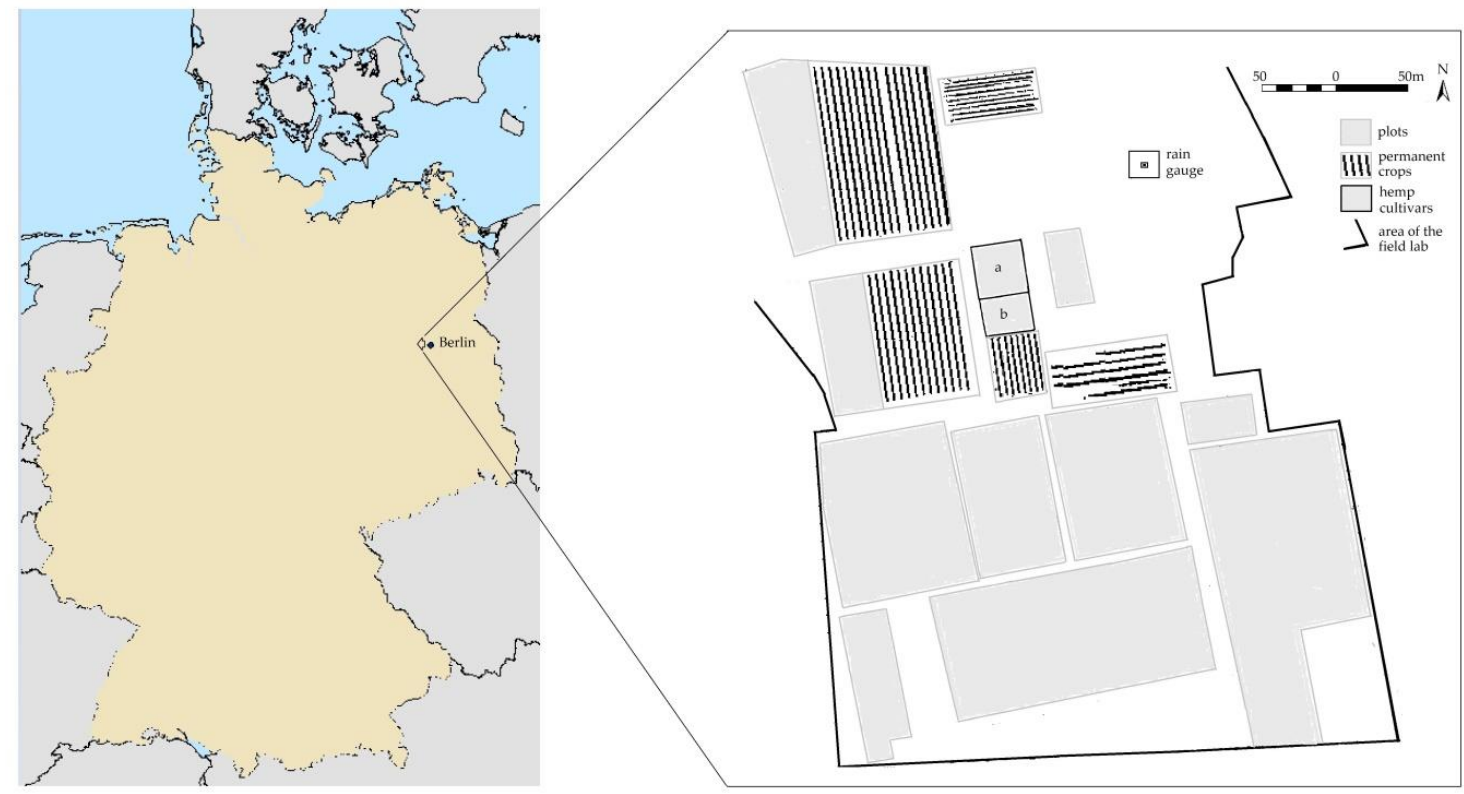

Figure 1. Location of the research site "Marquardt Fieldlab for Digital Agriculture", the rain gauge, and the plots of the two cultivars "Santhica 27" (a) and "Ivory" (b).

The soil type is a Eutric Lamellic Brunic Arenosol (Aric) [20] or more specifically low loamy sand SL2 [21]. The site is characterized by low soil fertility due to its limited water holding and cation exchange capacities. In the topsoil, the primary kinds of soil substrate are low to average silty sand. Soil physical properties of the topsoil are listed in Table A1.

At the research site, the groundwater table is $32 \mathrm{~m}$ above sea level [20] and the groundwater table depth is $10 \mathrm{~m}$ below the top ground surface.

Total area of the study site was 0.24 ha on which "Santhica 27" was cultivated on 0.12 ha and "Ivory" on 0.08 ha. The fallow period started after the harvest of the potato precrop ("Soraya") on 22/09/2017 and ended with the sowing of the next crop. Santhica 27 was sown on 04/05/2018. Measurements of $L A I$ and visual inspection of the plants were conducted on three plots with an area of $0.25 \mathrm{~m}^{2}$ each (Santhica 27 1, Santhica 27 2, Santhica 27 3), while those of Ivory were sown in the same way on 22/05/2018, both with a density of 200 seeds per $\mathrm{m}^{2}$ with an inter row distance of $12.5 \mathrm{~cm}$ and with $\mathrm{N}$-fertilization applied at $70 \mathrm{~kg} \mathrm{ha}^{-1}$. In May, $55 \mathrm{~kg} \mathrm{ha}^{-1}$ Kieserite $\left(\mathrm{MgSO}_{4} \mathrm{H}_{2} \mathrm{O}\right)$ was fed. Plants of both cultivars are characterized by distinct growth strategies as explained in detail by the authors in [22]. Measurements were conducted on three plots (Ivory 1, Ivory 2, Ivory 3). The whole vegetation period in 2018 and, in particular, the time of plant establishment, was characterized by extreme drought conditions. This was equally evident in the moderate to poor field emergence with only 75\% for Santhica 27 and only 30\% for Ivory. In order to prevent a total loss of the experimental basis, the study area was given sprinkler irrigation on 30/05/2018 with a $10 \mathrm{~mm}$ sprinkler ( $\left.W_{\text {irri }}\right)$. Plants of both cultivars were harvested, separated in selected components, weighed, and immediately oven dried on 19/09/2018. In particular, the area-specific output of bast beside the whole biomass yield was selected for further assessment of water productivity. The bast of specific crops is defined as tissue from secondary phloem and contains the fibers mainly used for added textile value from hemp. The yield, or more precisely the bast content, is easier to determine than its fibers.

Santhica 27 and Ivory were chosen as representatives from a large variety of trials, conducted under the framework of the MultiHemp project (http://multihemp.eu/). The French Santhica 27 is widely used in Europe, while Ivory had been a result of recent breeding activities in order to improve rettability. 


\subsection{Measurements}

\subsubsection{Leaf Area Index and Yield}

Starting on 15/06/2018, measurements of the leaf area index ( $L A I)$ and visual inspections of the plants (rating evaluations) on the total areas and on the three specific plots of $0.25 \mathrm{~m}^{2}$, randomly selected for each cultivar, were performed at weekly intervals on the total areas as repetitions. For $L A I$, leaves of small, medium-sized and large plants were each harvested and their area scanned (I-203 Handheld Laser Leaf Area Meter plus CA203CA conveyor attachment, CID Bio-Science, Inc., Camas, WA, USA). The $L A I$ was then calculated using the software GNU Image Manipulation Program 2.10.14 [23]. From the mean leaf area $(\overline{\mathrm{x}})$ of the $(\mathrm{n})$ plants on the specific plots in $\mathrm{m}^{2}$ per $0.25 \mathrm{~m}^{2}$, the average $L A I$ $\left[\mathrm{m}^{2} \mathrm{~m}^{-2}\right]$ of plants of each cultivar was estimated as Equation (1):

$$
L A I=\overline{\mathrm{x}} \times \mathrm{n} \times 4
$$

Within the specific areas of $0.25 \mathrm{~m}^{2}$ on each of the six plots, the height of ten plants and the total number of plants were determined. Based on these data, mean growth rates of plants of both cultivars were calculated over the entire vegetation period. The total mass yield at the specific inspection areas was determined at the harvest on 18 September 2018. For this, all plants were manually cut, sorted, and their fresh mass obtained; afterwards all plant parts were separated from each other and oven-dried for $24 \mathrm{~h}$ and their dry mass weighed.

For the calculation of the $L A I$ at the specific precipitation events, the arithmetical means of the two measurements before and after the incident were used.

\subsubsection{Soil Moisture}

In the area of each cultivar, five EC-5 soil moisture probes (Meter Group, Inc., Pullman, Wahington, DC, USA) were installed vertically at depths of $20 \mathrm{~cm}$. Soil moisture was measured hourly and monitored with the Meter Group, Inc. EM50R logger systems. The measurement area of probes was restricted by the length of the rods (i.e., $50 \mathrm{~mm}$ ). During the growing period (May to September), the mean soil moisture content was analyzed.

Soil bulk density was determined using seven samples, drawn from a depth of $20 \mathrm{~cm}$ at a distance of $100 \mathrm{~m}$ from the study site. Soil water retention curves were established by measuring the soil water content at four different soil water tensions, as indicated by its logarithmic values $(p F)$, of $0.0,1.8,2.4$, and 2.5 for each soil sample. The dimensionless $p F$ is defined as the decimal logarithm of the capillary head expressed in centimeters. Crop water availability was determined from the amount of water held between field capacity ( $p F 2.0)$ and the permanent wilting point ( $p F$ 4.2).

\subsubsection{Weather}

Hourly and daily values of precipitation $(P)$ were measured with a Hellmann-type tipping bucket rain gauge (ECRN-100, Meter Group, Inc., Pullman, Wahington, DC, USA) at the Marquardt research site at a distance of $120 \mathrm{~m}$ from the study area. Meteorological data were obtained from the Potsdam station (DWD_05825_Potsdam) of the German Weather Service (DWD), located approximately $10 \mathrm{~km}$ from the research site. Temperature (air, soil), humidity, wind (speed, direction), global radiation, and sunshine duration were measured at hourly resolution. With a mean annual precipitation of $579 \mathrm{~mm}$ in e.g., Potsdam (Table A2), Brandenburg ranks among the driest regions in Germany and Europe [24].

\subsubsection{Gas Exchange Measurement}

Water vapor and $\mathrm{CO}_{2}$ exchange of leaves of the two hemp cultivars were measured with a portable $\mathrm{CO}_{2} / \mathrm{H}_{2} \mathrm{O}$-exchange system (Ciras-1, PP Systems Europe, Hitchin, UK) between 9 AM and 2 PM for 22 days during 17 weeks of the growing season. During measurements, leaf temperature in the PLC 4 
cuvette (PP Systems Europe, Hitchin, UK) was automatically monitored as closely as possible (29.6 \pm $3.6^{\circ} \mathrm{C}$ and $27.0 \pm 2.5^{\circ} \mathrm{C}$ for Santhica and Ivory plants, respectively) under the extreme temperature conditions and the photosynthetic photon flux rates were set at approximately $1100 \pm 55 \mu \mathrm{mol} \mathrm{m}^{-2}$ $\mathrm{s}^{-1}$ with the respective PP Systems lighting equipment (fitted with blue and red LED) on top of the cuvette. Measurements were conducted on three single leaves of four plants per plot. From the monitored data of gas exchange, leaf temperature, gas flow and $\mathrm{CO}_{2}$ and water vapor concentration in the cuvette, rates of transpiration $\left(J_{\mathrm{H} 2 \mathrm{O}}\right)$, net $\mathrm{CO}_{2}$ exchange $\left(J_{\mathrm{CO} 2}\right)$, stomatal conductance for water vapor transfer $\left(g_{\mathrm{H} 2 \mathrm{O}}\right)$, and leaf internal $\mathrm{CO}_{2}$ molar fraction $\left(c_{\mathrm{i}}\right)$ were calculated after [25] as summarized by [26]. Water use efficiency values were derived from $J_{\mathrm{CO} 2}, J_{\mathrm{H} 2 \mathrm{O}}$ and $g_{\mathrm{H} 2 \mathrm{O}}$ the instantaneous $\left(W U E_{\mathrm{J}}=\right.$ $\left.J_{\mathrm{CO} 2} / J_{\mathrm{H} 2 \mathrm{O}}\right)$ and the intrinsic $\left(W U E_{\mathrm{g}}=J_{\mathrm{CO} 2} / g_{\mathrm{H} 2 \mathrm{O}}\right)[26]$. Furthermore, the $\mathrm{c}_{\mathrm{i}} / \mathrm{c}_{\mathrm{a}}$ ratio, which indicates the degree of stomatal limitations, was calculated.

\subsubsection{Throughfall}

Five rain gauge systems were installed in the area of each cultivar to measure throughfall. Troughs of various sizes, funnels, and rain gauges were used. Although rain gauges are frequently relocated randomly [27], in the present experiment they were arbitrarily installed at fixed positions within the plot. In addition, two plastic funnels with an open section of $50 \mathrm{~cm} \times 4 \mathrm{~cm}$ were used to enlarge the rain-harvesting surface and lead the throughfall to the tipping bucket of a high-resolution (0.2 mm per tip) rain gauge (ECRN-100 with EM50R data logger, Meter Group, Inc., Pullman, WA, USA) to overcome the assumed variability of throughfall. To avoid unacceptable damage to the cultures, roving gauges were not used to improve the representativeness of sampling [27]. Rain gauge and funnels were protected with mesh, and the rain gauge additionally with a $10 \mathrm{~L}$ vessel. Measurements were conducted hourly during the whole vegetation period from May to September.

\subsection{Calculations}

\subsubsection{Hydrological Variables}

The volumetric water content $\left(V W C, \mathrm{~m}^{3} \mathrm{~m}^{-3}\right)$ was calculated from the EC-5 soil moisture probe measurements using no specific calibration curve Equation (2) (Meter Group, Inc., Pullman, Wahington, DC, USA),

$$
V W C=0.00119 \times V O-0.4
$$

where $V O(\mathrm{mV})$ is the voltage output of the EC-5 soil moisture probe. The gravimetric water storage (SWS) of the soil at a specific time over a specific depth of the soil layer was calculated as (3):

$$
S W S=V W C \times D \times B D
$$

where $V W C\left(\mathrm{~kg} \mathrm{~kg}^{-1}\right)$ is the mean volumetric water content at a specific time, $D(\mathrm{~m})$ the depth of the soil layer, and $B D\left(\mathrm{~kg} \mathrm{~m}^{-3}\right)$ the bulk density of the soil. SWS is given here in [mm], assuming a water density of $1 \mathrm{~kg} \mathrm{~L}^{-1}$.

Evaporation of intercepted water within the vegetation period was calculated as Equation (4):

$$
I=P-T F(+S F)
$$

where $I(\mathrm{~mm})$ is the evaporation of intercepted water, $P(\mathrm{~mm})$ the incident rainfall, $T F(\mathrm{~mm})$ the throughfall, and SF ( $\mathrm{mm}$ ) the stemflow. Since SF was not measured, I will be overestimated.

The water flows over the vegetation period were calculated on a daily basis with the modeling software AgroHyd Farmmodel [28]. With the model, water flows can be systematically quantified at different scales, from the farm scale using individual farm operating data up to the regional scale on a daily time step. Local climate, from the climate station operated by the DWD, crop data, and soil data from the BÜK 300 [20] were combined in a modeling unit for a detailed calculation of the local 
hydrologic processes: evaporation from soil $(E)$, transpiration $(T)$, evaporation of intercepted water $(I)$, and percolation. The crop data were taken on one hand from the inspection of the plants and on the other hand the basal crop coefficients $(K c b)$ were calculated using measured transpiration and then modeled following $E T_{0}$ (Equation 5) for each cultivar [29]. For root length, published data were used [30]

$$
T=K c b \times E T_{0}
$$

The algorithm for calculating the actual crop transpiration $\left(T_{\text {act }}\right)$ in the Agrohyd Farmmodel is based on the FAO 56 dual crop coefficient method [29]. This requires calculating the reference evapotranspiration $\left(E T_{0}\right)$, the potential crop evapotranspiration $\left(E T_{\mathrm{c}}\right)$, and the actual evapotranspiration $\left(E T_{\text {act }}\right)$. Implemented in the AgroHyd Farmmodel, the reference evapotranspiration of a grass reference surface is calculated using the FAO Penman-Monteith equation with regional climate data [29]. Subsequently, reference evapotranspiration is adjusted for the individual crop with plant-specific parameters, e.g., the plant-specific basic crop coefficient $(K c b)$, to calculate the potential crop transpiration $\left(T_{\mathfrak{c}}\right)$. A daily soil water balance using a simple tipping bucket approach is combined with regional soil and precipitation data to find the water (deficit) stress coefficient $\left(K_{\mathrm{S}}\right)$ that reduces $T_{\mathrm{c}}$ to $T_{\text {act }}$ [29]. Thus, the calculation of $T_{\text {act }}$ incorporates the effect of daily water deficit stress by linking the data sets on plants and soil characteristics. In addition, the deep percolation of water through the soil, the total available soil water in the root zone, the root zone depletion, the evaporation, and the reference evapotranspiration are calculated following [29]. A detailed description of the model was given in $[28,31]$.

For the evaluation of the modeling results, simulated values were compared to measured values for actual transpiration and for evaporation of intercepted water based on measurements.

\subsubsection{Water Productivity of the Hemp}

Water productivity was calculated according to [31] to characterize the effective water use of plants of the two hemp cultivars. Water input $\left(W_{\text {input }}\right)$ is the sum of all components of water inflow via air and ground that are used for crop growth, i.e., transpired water stemming from precipitation $\left(W_{\text {prec-trans }}\right)$, all water inflow via technical means $\left(W_{\text {tech }}\right)$, and indirect water use referring to pre-chains, e.g., for fertilizer ( $\left.W_{\text {indirect }}\right)$, Equation (6):

$$
W_{\text {input }}=W_{\text {prec-trans }}+W_{\text {tech }}+W_{\text {indirect }}
$$

$W_{\text {tech }}$ comprises irrigation water $W_{\text {irri }}$ and tap water $W_{\text {tap }}$.

In this study, $W_{\text {indirect }}$ was not considered, because the indirect water for the production of fertilizers, machinery, and infrastructure was assumed to be negligible [32]. The same applies for the $W_{\text {tap. }}$ Therefore, Equation (6) for water inflow was reduced to:

$$
W_{\text {input }}=W_{\text {prec-trans }}+W_{\text {irri }}
$$

Water productivity can be expressed as Equation (7):

$$
W P_{\text {mass }}=\frac{M a s s_{\text {output }}}{W_{\text {input }}}
$$

$W P_{\text {mass }}$ denotes the fresh or dry mass-based water productivity $\left[\mathrm{t} \mathrm{m}^{-3}\right]$, while $W_{\text {input }}$ is the water input $\left[\mathrm{m}^{3}\right.$ year $\left.^{-1}\right]$ and Mass $_{\text {output }}$ the fresh/dry mass output $\left[t\right.$ year $\left.^{-1}\right]$. 


\subsubsection{Statistical Analyses}

For the analysis of the differences of the measured water fluxes of seven precipitation events and $L A I$ of plants of Santhica and Ivory, the unpaired t-test $(\alpha=5 \%)$ was used. A parametric least square linear regression test was used [33] to analyze the relationship between precipitation and throughfall.

For the evaluation of the performance of the AgroHyd Farmmodel, the measured actual transpiration was compared with the modeled transpiration. A parametric least squares linear regression test with Pearson's correlation coefficient $(r)$ was used to assess the proportion of variance in measured data explained by the model [33]. Furthermore, the model evaluation statistics Nash-Sutcliffe efficiency (NSE), logarithmic Nash-Sutcliffe efficiency ( $N S E_{\log }$ ), root mean square error (RMSE) and percent BIAS (PBIAS) were used for model evaluation following [34-36].

\subsubsection{Sources of Uncertainty}

The extrapolation of the calculated gravimetric water storage (SWS) of the soil over the depth of 2 $\mathrm{m}$ the soil layer is associated with uncertainties, because the measurement was done over the length of the probes of $50 \mathrm{~mm}$. The following sources of uncertainty in the water fluxes were considered: (1) natural randomness, (2) input data, and (3) model parameters and model structure. The uncertainties were evaluated based on the experimental approach.

(1) Natural randomness $\left(X_{N}\right)$

As a measure of natural randomness, the range and the standard deviations and errors of incident precipitation $\left(X_{\mathrm{N}, \mathrm{P}}\right)$ and throughfall $\left(X_{\mathrm{N}, \mathrm{TF}}\right)$ in the period between May and September were used.

As a measure of natural randomness $\left(X_{\mathrm{N}, \mathrm{P}}\right)$, the coefficient of variation $(\mathrm{CV})$ resulting from the ratio of the standard deviation to the mean of precipitation was used.

(2) Input data $\left(X_{\mathrm{I}}\right)$

The error of Hellmann-type gauges ranges from 2 to $12.5 \%$ for rainfall intensities between 25 and $0.01 \mathrm{~mm}$, but it also depends on wind speed. At a wind speed of $5 \mathrm{~m} \mathrm{~s}^{-1}$, the error is less than $5 \%$ [37]. The uncertainty resulting from the spatial distribution of precipitation was considered as negligible. The hourly measured and logged incident precipitation at the meteorological station in Marquardt is affected by the same error as the Hellmann-type gauges $\left(X_{I, P}\right)$. The error of the throughfall measurement was assessed by orienting towards the nomogram of [27] $\left(X_{\mathrm{I}, \mathrm{TF}}\right)$. For the uncertainty assessment, the standard deviations of dry and fresh mass-based yields $\left(X_{\mathrm{I}, \mathrm{Y}}\right)$ of the two harvest components, whole plant and bast, were used.

(3) Model parameters, model structure (XM)

To calculate the structural uncertainty of the modeling process, resulting from model parameters and model structure, the standard deviation of the differences (SD) of the transpiration (SDT) was used.

To quantify the overall uncertainty of the calculated WP values, the uncertainty of output measurement and $W_{\text {input }}$ modeling were considered. Then, the alternative WP was calculated using minimum and maximum values of all output and $W_{\text {input }}$.

\section{Results and Discussion}

\subsection{Leaf Area Index and Yield}

The LAI-values of Santhica 27 plants were higher than those of Ivory plants. The measured LAI varied between 0.6 and 8.8 depending on cultivar and development of the crops. Tang et al. (2020) [14] reported average $L A I$ between 3.2 and 4.8 at the linear growth stages and full flowering under an $\mathrm{N}$-fertilization of $60 \mathrm{~kg} \mathrm{ha}^{-1}$ without an additional application of Kiserit. These values are similar to the means of $4.6 \pm 2.4$ measured in the present study, which consistently showed a clear maximum for the two cultivars on 20/07/2018 with 8.8 for Santhica and 7.5 for Ivory. The unpaired t-tests indicated a significant difference between the LAI of plants of the two cultivars. Based on the LAI and the transpiration patterns, the development stages "initial season", "mid-season", and "late season" were derived for the modeling process. 
Santhica 27 plants showed higher yields than those of Ivory (Table 1). Amaducci et al. (2000) [38] found comparable average yields of $14.0 \mathrm{t} \mathrm{ha}^{-1}$ of total dry mass for fiber hemp and of $10.9 \mathrm{tha}^{-1} \mathrm{of}^{\mathrm{f}}$ stems for crops cultivated in Northern Italy. Struik et al. (2000) [9] reported higher yields of $25 \mathrm{tha} \mathrm{h}^{-1}$ total above ground dry mass and of $20 \mathrm{t} \mathrm{ha}^{-1}$ for stems of crops cultivated in Europe.

Table 1. Plant density, dry mass yields $(D M)$, and fresh mass yields $(F M) \pm$ standard deviations.

\begin{tabular}{lcc}
\hline & Santhica 27 & Ivory \\
\hline Plant density $_{\text {start growing period }}$ plants $^{-2}$ & 149 & 60 \\
Plant density harvest $^{\text {plants m}}{ }^{-2}$ & 79 & 43 \\
$F M_{\text {whole plant }}$ tha $^{-1}$ & $24.5 \pm 10.3$ & $14.4 \pm 6.3$ \\
$D M_{\text {whole plant }}$ tha $^{-1}$ & $17.9 \pm 6.3$ & $10.0 \pm 3.9$ \\
$F M_{\text {bast }}$ ha $^{-1}$ & $6.3 \pm 2.6$ & $4.2 \pm 1.9$ \\
$D M_{\text {bast }}$ tha $^{-1}$ & $2.8 \pm 0.8$ & $2.1 \pm 0.9$ \\
\hline
\end{tabular}

The crops showed a self-thinning effect, i.e., plant density declined by $47 \%$ (Santhica 27) and by $29 \%$ (Ivory) during growth (Table 1). In comparison with results reported for self-thinning of 50\% and $60 \%$ for high densities [38], the values found in the present study were lower for Ivory but similar for Santhica 27 plants.

\subsection{Hydrological Variables for the Vegetation Period of Hemp}

\subsubsection{Soil Moisture Measurements}

Crop water availability was determined to be $18 \pm 1 \%$ (Table A2). A mean dry bulk density of $1.44 \pm 0.09 \mathrm{~g} \mathrm{~cm}^{3}$ was measured in the topsoil of the research site. Means of $V W C$ did not differ between plants of Santhica $(n=5)$ and those of Ivory $(n=5)$. The variations in soil moisture measured during the whole growth stage were considered. The mean soil water content was $17 \pm 2 \%(n=10)$ as measured hourly in 10 positions during May to September, while the maximum was $30 \%$ and the minimum 14\%. The FD-probes measurements indicated a decrease in soil water content at a constant low variance $(0.06 \%)$ as the season progressed, without any response to precipitation events occurring after one rainfall event of $19.6 \mathrm{~mm}(11 / 07-12 / 07)$ (Figure 2). Due to the extremely dry and hot climate in 2018 it seems possible that the precipitation water of the other events evaporated before reaching the depth of the probes $(20 \mathrm{~cm})$. Another possibility is a surface runoff of the rainfall resulting from a hydrophobicity of the sandy soil or a combination of these two possible reasons.

The difference between the gravimetric soil water storage (SWS) of the soil at the beginning (May 2018) and the end of the vegetation period (September 2018) was $137 \mathrm{~mm}$. This can be considered as water that was available to the hemp plants in addition to the precipitation. This value is associated with large uncertainties due to the extrapolation of measurements conducted at a depth of $30 \mathrm{~cm}$ over a length of $5 \mathrm{~cm}$ to a depth of $2 \mathrm{~m}$. 


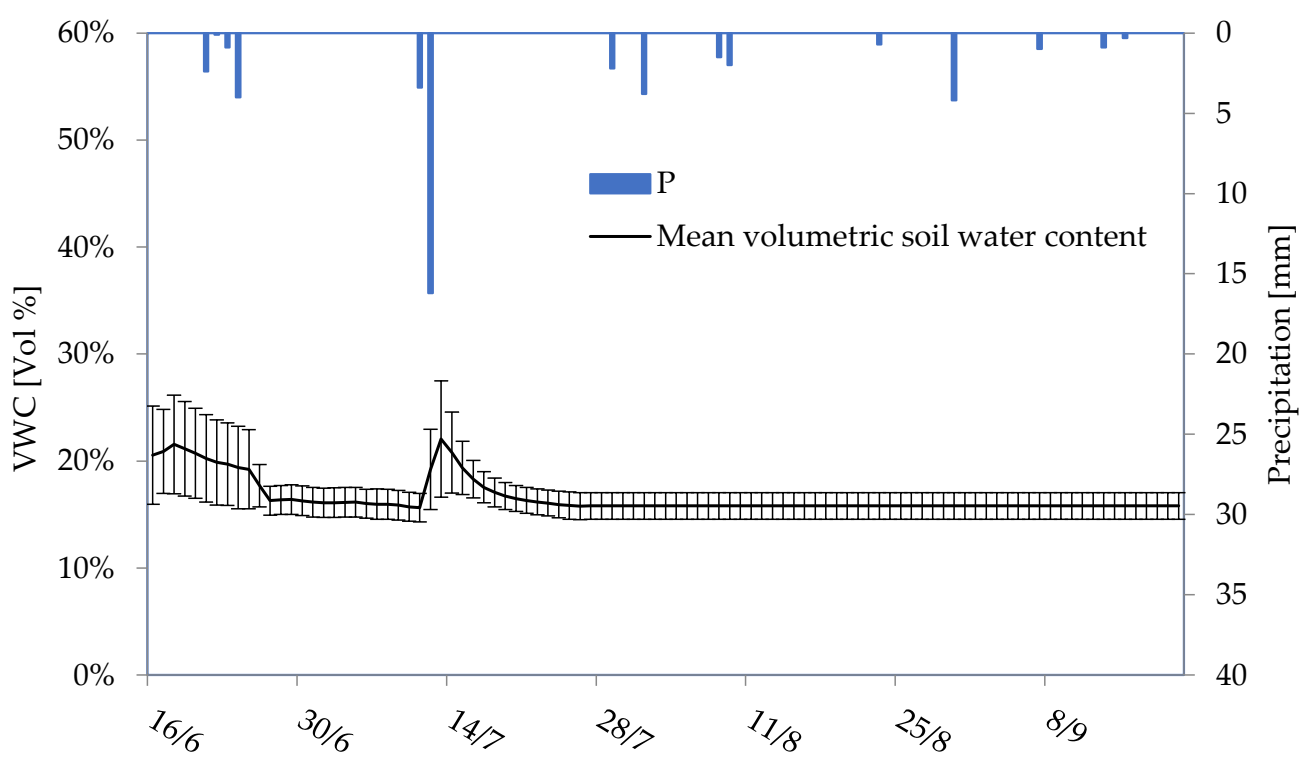

Figure 2. Precipitation $(P)[\mathrm{mm}]$ and means of the volumetric water content $V W C[\%] \pm$ standard deviation $(n=10)$ measured under the hemp plants of both Santhica and Ivory.

\subsubsection{Water Fluxes for Seven Measured Precipitation Events}

\section{Precipitation Events and Throughfall}

Within the vegetation period May to September of 2018, seven precipitation events occurred with a mean hourly volume of $6.2 \mathrm{~mm}$. The largest amount was $19.6 \mathrm{~mm}$, and the smallest was $0.7 \mathrm{~mm}$. The throughfall of the seven events, determined on the 10 measuring points of throughfall and soil water content, resulted in 70 throughfall values. Due to highly probable logger failure, 16 values showing an amount of $0 \mathrm{~mm}$ were eliminated. The unpaired t-test yielded no significant difference between the values of TF for Santhica $(n=5)$ and Ivory $(n=5)$. The mean throughfall value was $1.9 \mathrm{~mm}$, the largest amount $8.2 \mathrm{~mm}$, and the smallest $0.1 \mathrm{~mm}$. The relationship between throughfall and precipitation is shown in (Figure 3). The regression analysis indicated a significant relationship between $T F$ and $P$, with the latter explaining $89 \%$ of the observed variation in throughfall.

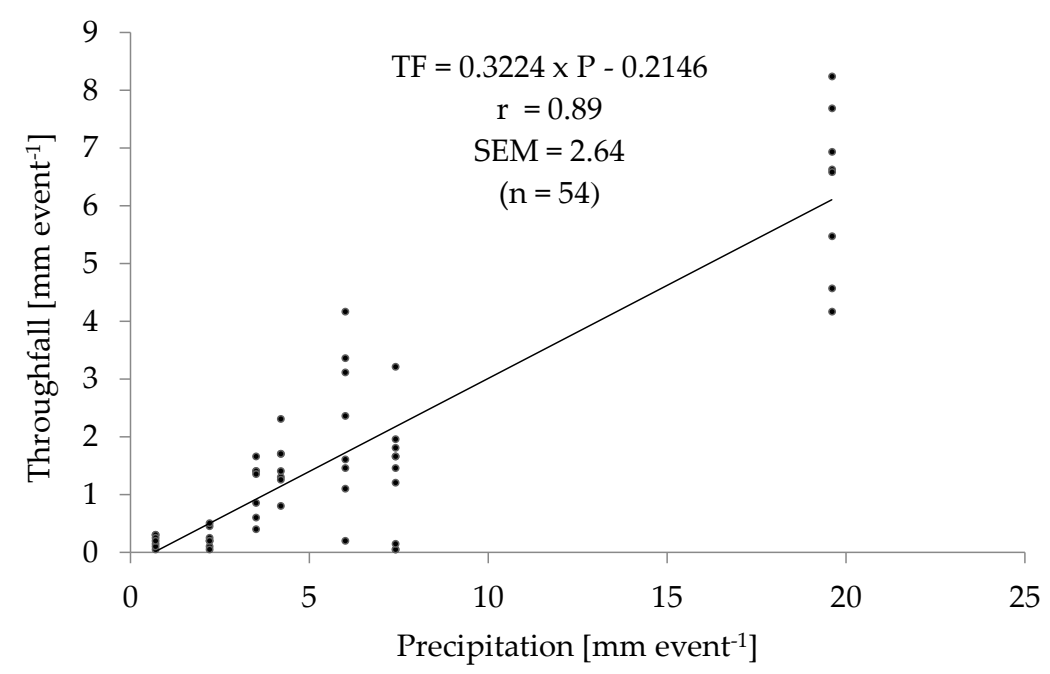

Figure 3. Relationship between throughfall $(T F)[\mathrm{mm}]$ and precipitation $(P)[\mathrm{mm}]$ for seven precipitation events between May and September 2018 with Pearson's correlation coefficient $(r)$ and standard error of the mean $(S E M)$. 
Evaporation of Intercepted Water

The evaporation of intercepted water $(I)$ was calculated using the $54 T F$ values for the seven precipitation events. The unpaired t-test resulted in no significant difference between means of $I$ for Santhica $(n=23)$ and Ivory $(n=31)$. The variations of $I$ calculated for the seven precipitation events measured during the vegetation period of the two hemp cultivars are considered in the following. The mean $I$ was $4.7 \mathrm{~mm}$, the largest amount was $15.4 \mathrm{~mm}$, and the smallest was $0.4 \mathrm{~mm}$. The relationship between precipitation and evaporation of intercepted water was significant for the seven events as for throughfall; precipitation explained 97\% (Figure 4) of the observed variation in evaporation of intercepted water.

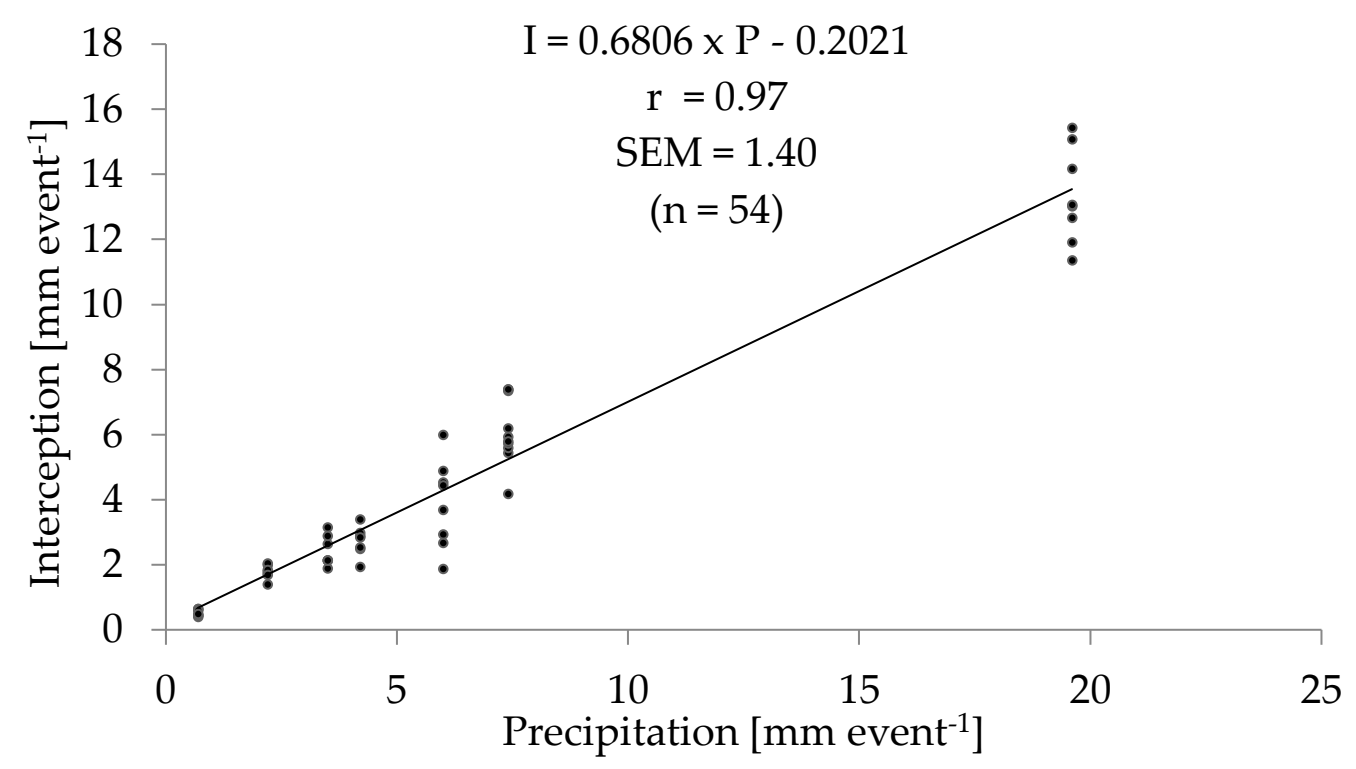

Figure 4. Relationship between precipitation $(P)$ and evaporation of intercepted water $(I)$ with Pearson's correlation coefficient $(r)$ and standard error of the mean (SEM).

The evaporation of intercepted water above the ten TF gauges correlated with the LAI (Figure 5). However, the $L A I$ explained only $27 \%$ of the observed variation in evaporation of intercepted water. Besides the $L A I$, the plant architecture and the meteorological conditions during the cropping cycle seem to be the main factors determining $I$ in the case of the two cultivars. 


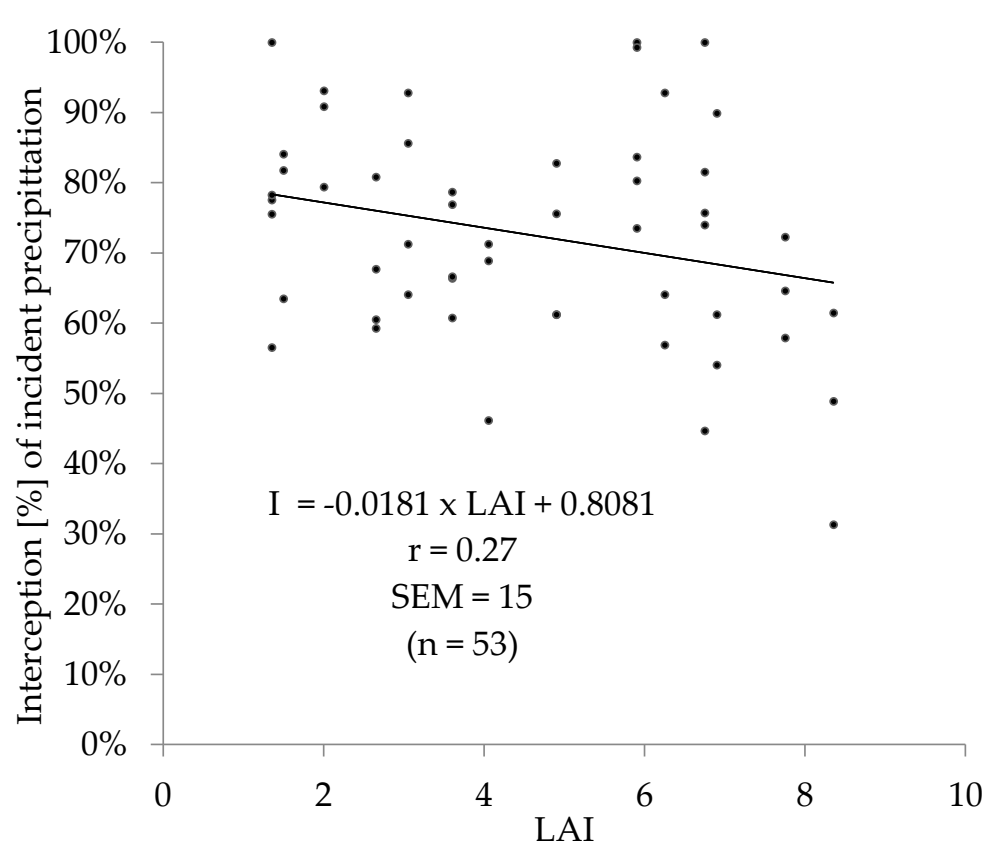

Figure 5. Relationship between $L A I$ (leaf area index) and the evaporation of intercepted water [\%] of incident precipitation with Pearson's correlation coefficient $(r)$ and standard error of the mean (SEM).

\subsubsection{Measured and Calculated Water Fluxes}

\section{Hourly Measured Precipitation and Throughfall}

Within the vegetation period, the hourly measurements of the precipitation at the climate station resulted in 97 hourly measurements between 16/06-20/09. The mean precipitation was $0.4 \mathrm{~mm}$. The largest amount was $16.2 \mathrm{~mm}$, and the smallest was $0.4 \mathrm{~mm}$.

During the same period, hourly measurements of throughfall and evaporation of intercepted water on the 10 plots resulted in 825 measurements. After 11/07, no precipitation had been recorded at two measuring points of Santhica 27. These data were eliminated because a logger failure was highly probable. In general, means of throughfall were not significantly different for Santhica $(n=437)$ and Ivory $(n=388)$. The variations of $T F$ and I measured each hour for both cultivars were considered in the following. The mean throughfall was $0.1 \pm 0.7 \mathrm{~mm}$, that of evaporation of intercepted water was $0.3 \pm 1.2 \mathrm{~mm}$, maxima were $8.2 \mathrm{~mm}(T F)$ and $12.0 \mathrm{~mm}(I)$, while the minima of both parameters were $0.0 \mathrm{~mm}$.

\section{Evaporation of Intercepted Water}

Differences between the water flux throughfall, evaporation of interception, and soil moisture of the Santhica and Ivory plants, obtained between 15/06/and 09/09/, were insignificant (Table 2). The estimated mean evaporation of intercepted water in the above period varied between 66 and 77\% of the incidental rainfall. Evaporation of intercepted water was higher for Ivory plants. 
Table 2. Measured precipitation $(P)$ and throughfall (TF), and calculated evaporation of intercepted water $(I)$ and $L A I( \pm$ SD) determined between 15/06/2018 and 09/09/2018.

\begin{tabular}{lccc}
\hline \multicolumn{3}{c}{ Cultivar } \\
\hline & Santhica 27 & Ivory & Mean \\
\hline$P[\mathrm{~mm}]$ & $44 \pm 2$ & $44 \pm 2$ & $44 \pm 2$ \\
$T F[\mathrm{~mm}]$ & $15 \pm 1$ & $11 \pm 4$ & $13 \pm 3$ \\
$T F[\%$ of $P]$ & 34 & 26 & $30 \%$ \\
$I[\mathrm{~mm}]$ & $29 \pm 1$ & $33 \pm 3$ & $31 \pm 2$ \\
$I[\%$ of $P]$ & 66 & 77 & 71 \\
$L A I$ & $5.8 \pm 2.5$ & $3.4 \pm 2.2$ & $4.6 \pm 2.4$ \\
\hline
\end{tabular}

Measured Transpiration

Daily transpiration measurements on the 10 plots (total $n=72$ ) resulted in a significant difference between the means for Santhica $(n=36)$ and those for Ivory $(n=36)$, with higher results for Santhica (Table 3).

Table 3. Mean $( \pm S D)$, maximum and minimum daily transpiration $(T)$ determined between 15/06/2018 and $09 / 09 / 2018$.

\begin{tabular}{lccc}
\hline & & Santhica 27 & Ivory \\
\hline & Mean & $5.90 \pm 3.11$ & $3.56 \pm 2.64$ \\
daily transpiration $(T)[\mathrm{mm}]$ & Max & 11.63 & 10.30 \\
& Min & 1.03 & 0.47 \\
& Mean & $5.90 \pm 3.11$ & $3.56 \pm 2.64$ \\
& Max & 11.63 & 10.30 \\
\hline
\end{tabular}

\subsubsection{Modeled Water Fluxes}

Parametrization of the AgroHyd Farmmodel

The vegetation period of Santhica 27 and Ivory plants and plant-specific parameters used to model the hydrologic processes for the two cultivars and the precedent fallow period with the AgroHyd Farmmodel were shown in Table 4. Transpiration and LAI measured on selective days allowed for the derivation of calculation of the plant-specific phases Table 4. Furthermore, the measured $T$ allowed for the calculation of and the basal crop coefficients for each cultivar.

Table 4. Plant-specific parameters for the crop-related modelling ( $p$ : evapotranspiration depletion factor, $\mathrm{Zr}$ : effective rooting depth, $K c b$ : basal crop coefficient, $L A I$ : leaf area index).

\begin{tabular}{|c|c|c|c|c|c|c|c|}
\hline \multirow{2}{*}{$\begin{array}{l}\text { Cultivar } \\
\text { Phase }\end{array}$} & \multicolumn{3}{|c|}{ Santhica 27} & \multicolumn{3}{|c|}{ Ivory } & \multirow{2}{*}{$\begin{array}{c}\text { Fallow } \\
-\end{array}$} \\
\hline & Initial & $\begin{array}{c}\text { Mid- } \\
\text { Season }\end{array}$ & $\begin{array}{c}\text { Late } \\
\text { Season }\end{array}$ & Initial & $\begin{array}{c}\text { Mid- } \\
\text { Season }\end{array}$ & $\begin{array}{c}\text { Late } \\
\text { Season }\end{array}$ & \\
\hline Start day & 1 & 77 & 91 & 1 & 59 & 80 & 1 \\
\hline End day & 76 & 90 & 138 & 58 & 79 & 120 & $\begin{array}{l}224 \text { (Santhica) } \\
242 \text { (Ivory) }\end{array}$ \\
\hline$p(-)$ & 0.5 & 0.5 & 0.5 & 0.5 & 0.5 & 0.5 & 0.55 \\
\hline $\mathrm{Zr}(\mathrm{m})$ & & 2.5 & & & 2.5 & & 0.3 \\
\hline Height (m) & & 2.049 & & & 1.585 & & 0.3 \\
\hline$K c b(-)$ & 0.3 & 1.82 & 0.62 & 0.54 & 1.11 & 0.43 & 0.15 \\
\hline$L A I\left(\mathrm{~m}^{2} \mathrm{~m}^{-2}\right)$ & & 8.8 & & & 7.6 & & 0.2 \\
\hline Vegetation period & & $5 / 18-09 / 0$ & $/ 18$ & & $5 / 18-09 / 0$ & $/ 18$ & $22 / 09 / 2017-05 / 2018$ \\
\hline
\end{tabular}


Performance of the Model

The first results of the modeling of the local hydrologic processes gave values for the actual transpiration that were too low (Figure 6a).
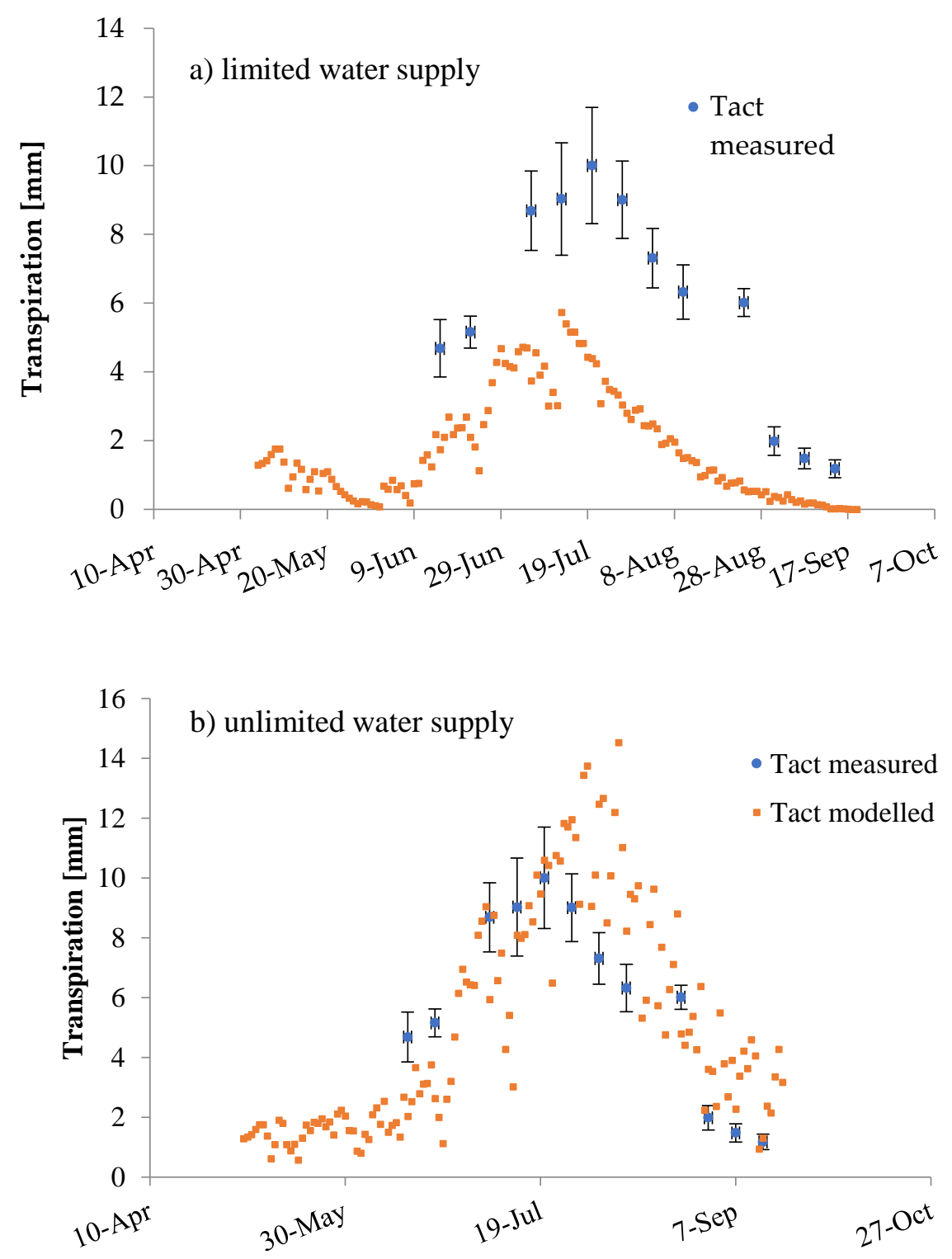

Figure 6. Mean measured actual transpiration ( $\pm \mathrm{SD} ; n=3)$ and modeled transpiration $\left(T_{\text {act }}\right)$ for Santhica; (a) modeled with limited water supply, (b) modeled with unlimited water supply.

The simulation of mean daily transpiration assuming unlimited water supply (Figure 6b) yielded better results than estimations based on water limitations (Figure 6a) as clearly highlighted by the comparison of measured and modeled values (Figure 6a,b; Table A3). In this context, unlimited water supply means that hemp roots accessed the capillary rise of the groundwater table, which is located at a $10 \mathrm{~m}$ depth at the research site.

The smallest y-intercept of the standard regression analyses of measured and modeled mean daily transpiration yielded the modeling of transpiration of Ivory, implying unlimited water supply (Table A3). In addition, the latter approach obtained a slope of 1 in this study. These results indicated the high performance of the model because a slope of 1 and y-intercept of 0 would reveal that the model perfectly reproduces the measured data [39]. 
The Pearson's correlation coefficient (r) describes the proportion of the variance in measured data explained by the model, which ranged between 0.80 and 0.92 in the present study. So, not all parameters affecting the transpiration were sufficiently explained by the regression. In addition, coefficients of determination $\left(R^{2}\right)$ in the range from 0.63 to 0.84 indicated low error variance and may, thus, be considered as well acceptable for the transpiration measurements, especially for $n=10[40,41]$. Only the assumption of unlimited water supply showed acceptable NSE and $N S E_{\log }$ values (>0.5) for both cultivars, while modeling based on limited water supply resulted in unacceptable values at least for $N E S_{\log }$. Here, the peaks resulting from higher transpiration influenced the model's performance. The model assuming unlimited water supply for both cultivars resulted in lower RMSE in comparison with that assuming unlimited water supply, which also yielded an unacceptable underestimation of the transpiration with a PBIAS $>40$ [42]. The standard errors $\left(S E_{\mathrm{T}}\right)$ of the transpiration measurements, which represent the structural uncertainty of the modeling process [43], do not point to large differences between the model assumptions; the modeling approach seems to have an acceptable performance for the two cultivars.

Summarizing these above results, it is quite obvious that modeling of the transpiration assuming limited water supply underestimated the measured transpiration especially for the transpiration peaks in mid-July. With certainty, plants of both cultivars accessed water from another source than precipitation. Most probably, roots reached the capillary fringe above the water table at a depth of $10 \mathrm{~m}$.

\section{Modeled Transpiration}

Modeling based on unlimited water supply did not reveal significant differences between the estimated mean daily transpiration for plants of both Santhica $(n=203)$ and Ivory $(n=201)$. Transpiration was clearly, though insignificantly, higher for Santhica 27 plants (Table 5).

Table 5. Mean $( \pm \mathrm{SD})$, maximum and minimum daily transpiration $\left(T_{\text {daily }}, \mathrm{mm}\right)$, modeled for the period between 15/06/2018 and 09/09/2018.

\begin{tabular}{lcc}
\hline & Santhica 27 & Ivory \\
\hline Mean & $6.64 \pm 3.35$ & $4.14 \pm 1.93$ \\
Max & 14.54 & 7.86 \\
Min & 0.94 & 0.59 \\
\hline
\end{tabular}

The total amounts of modeled transpiration ( $T_{\text {crop }}$ ), added up for the time between 15/06/2018 and 09/09/2018, similarly indicated that plants of Santhica 27 transpired nearly double the amount transpired by Ivory (Table 6). In this context, the modeled total transpiration per vegetation period for the former was well within the range reported by [12] for hemp plants cultivated in the UK (500-700 $\mathrm{mm})$, while the value for Ivory was essentially lower.

Table 6. Precipitation $(P)$ and modeled actual transpiration $(T)$ determined for the fallow period ( $T_{\text {fallow }}$ ) starting from $21 / 09 / 2017$ and for the vegetation period $\left(T_{\text {crop }}\right)$ between the two cultivars.

\begin{tabular}{lcc}
\hline & Cultivar \\
\hline & Santhica 27 & Ivory \\
\hline$P_{\text {fallow }}[\mathrm{mm}]$ & 243 & 243 \\
$T_{\text {fallow }}[\mathrm{mm}]$ & 31 & 31 \\
$P_{\text {crop }}[\mathrm{mm}]$ & 44 & 44 \\
$T_{\text {crop }}[\mathrm{mm}]$ & 633 & 398 \\
\hline
\end{tabular}

\subsection{Uncertainties and Water Budget}

Errors and uncertainties of precipitation were generally small (Table A4). The error of the measured incidental precipitation $(P)$ may be low because of the high reliability of Hellmann-type rain gauges. 
In addition, the short distance of $120 \mathrm{~m}$ between weather station and plots may further contribute to the low variance. Nevertheless, the measurement of $P$ might be associated with an error due to wind field deformation above the gauge orifice. In contrast, the errors and uncertainties in throughfall (TF) measurements were large (Table A4). Throughfall is difficult to measure as a result of the potentially large spatial variability caused by the vegetation [27]. The small area of funnels compared with the total area of the individual plots might have resulted in an underestimation of the actual throughfall and, in turn, in overestimating the evaporation of intercepted water. Field measurements of TF must be planned and conducted with high care and expert knowledge, due to the various sources of uncertainty shown here. In addition, errors and uncertainties regarding the yield and the transpiration resulting from the uncertainty of model parameters and model structure were high.

In this study, evaporation from rainfall interception $(71 \%$ of $P)$ was at the upper end of values previously reported for agricultural crops worldwide [18]. If the propagation of the various sources of uncertainty was considered (Table 7), the mean range of the evaporation of intercepted water (48-77\%) was comparable to the upper range of several crops.

Table 7. Minimum and maximum estimates of mean fluxes between May and September for plants of both cultivars, including all errors in the experimental results.

\begin{tabular}{|c|c|c|c|c|}
\hline \multirow{2}{*}{\multicolumn{2}{|c|}{ Hydrologic Variables }} & \multicolumn{2}{|c|}{ Cultivar } & \multirow{3}{*}{ Mean } \\
\hline & & \multirow[t]{2}{*}{ Santhica 27} & \multirow[t]{2}{*}{ Ivory } & \\
\hline$P$ & $(\mathrm{~mm})$ & & & \\
\hline$T F$ & $\begin{array}{l}\max \\
\min \\
(\mathrm{mm})\end{array}$ & \multicolumn{2}{|c|}{$\begin{array}{l}46 \\
41\end{array}$} & \\
\hline$I$ & $\begin{array}{l}\max \\
\min \\
(\mathrm{mm})\end{array}$ & $\begin{array}{l}19 \\
14\end{array}$ & $\begin{array}{c}18 \\
8\end{array}$ & $\begin{array}{l}19 \\
11\end{array}$ \\
\hline$I$ & $\begin{array}{l}\max \left[I_{\max }=P_{\max }-T F_{\min }\right] \\
\min \left[I_{\min }=P_{\min }-T F_{\max }\right] \\
(\% \text { of } P)\end{array}$ & $\begin{array}{l}33 \\
22\end{array}$ & $\begin{array}{l}39 \\
23\end{array}$ & $\begin{array}{l}36 \\
22\end{array}$ \\
\hline$T$ & $\begin{array}{l}\max \left[I_{\max }=I_{\max } / P_{\max }\right] \\
\min \left[I_{\max }=I_{\min } / P_{\min }\right] \\
(\mathrm{mm})\end{array}$ & $\begin{array}{l}70 \% \\
47 \%\end{array}$ & $\begin{array}{l}84 \% \\
49 \%\end{array}$ & $\begin{array}{l}77 \% \\
48 \%\end{array}$ \\
\hline$T$ & $\begin{array}{l}\text { Max } \\
\text { Min } \\
(\% \text { of } P)\end{array}$ & $\begin{array}{l}914 \\
347\end{array}$ & $\begin{array}{l}521 \\
274\end{array}$ & $\begin{array}{l}717 \\
311\end{array}$ \\
\hline & $\begin{array}{l}\text { Max } \\
\text { Min }\end{array}$ & $\begin{array}{c}1978 \% \\
750 \%\end{array}$ & $\begin{array}{c}1127 \% \\
593 \%\end{array}$ & $\begin{array}{c}1552 \% \\
672 \%\end{array}$ \\
\hline
\end{tabular}

However, mean TF of plants of both cultivars accounted for 11 to $19 \%$ of the incidental rainfall for hemp in Brandenburg (Germany) and is thus lower than the reported values. Field measurements must be planned and conducted with a high degree of care and expert knowledge, due to the various sources of uncertainty shown here. For the calculation of the WP the minimum and maximum values of $W_{\text {input }}$ and all outputs are presented in Table A5.

\subsection{Water Productivity}

Water productivity of the hemp plants was higher in this study than that calculated for ten countries using modeled $E T_{0}$ with Aquacrop and that reported by [15,44]. Values reported by [15] for industrial hemp indicate a minimum of $0.19 \mathrm{~kg} \mathrm{~m}^{-3}$ for Turkey and a maximum of $2.4 \mathrm{~kg} \mathrm{~m}^{-3}$ for the Netherlands. In the present study, WP calculated for Santhica 27 plants was higher than that for Ivory except for the case of $W P_{\text {DMfiber bast }}$ (Table 8). 
Table 8. Results of the fresh mass (FM) and dry mass (DM)-based water productivity (WP) for whole plants and for fiber bast of plants of both cultivars.

\begin{tabular}{lccc}
\hline & & Santhica 27 & Ivory \\
\hline & $W P_{\text {FMwhole plant }}$ & 3.49 & 3.07 \\
$W P\left[\mathrm{~kg} \mathrm{~m}^{-3}\right]$ & $W P_{\text {DMwhole plant }}$ & 2.55 & 2.14 \\
& $W P_{\text {FM bast }}$ & 0.90 & 0.89 \\
& $W P_{\text {DM bast }}$ & 0.39 & 0.45 \\
\hline
\end{tabular}

The mean $W P_{\text {DMwhole plant }}$ of industrial hemp investigated in this study is about five times higher than that of seed cotton $\left(2.35 \mathrm{~kg} \mathrm{~m}^{-3}\right.$ vs. $\left.0.45 \mathrm{~kg} \mathrm{~m}^{-3}\right)$ published by [45,46]. Perović et al (2019) [45] published a fiber-related WP of $0.25-0.27 \mathrm{~kg} \mathrm{~m}^{-3}$ water input for Australian irrigated cotton. For seed cotton cultivated in Northwest China, Shareef et al. (2018) [46] found values between $0.41-0.48 \mathrm{~kg} \mathrm{~m}^{-3}$.

It has to be noted that in this study only the output of bast and not the output of fibers was determined. According to [47], the share of fiber in bast is $60 \%$.

After the propagation of the various sources of the uncertainties, WP was calculated using minimum and maximum values of all outputs and $W_{\text {input }}$ (Table 9). The combined experimental and modeling approach to calculate water productivity of plants of both cultivars contained many sources of error.

Table 9. Minimum (min) and maximum (max) estimates of fresh mass (FM) and dry mass (DM)-based water productivity $(W P)$ for whole plants and for bast fibers of plants of both cultivars, including all errors of the experimental results.

\begin{tabular}{|c|c|c|c|c|}
\hline$W P\left[\mathrm{~kg} \mathrm{~m}^{-3}\right]$ & & $\begin{array}{c}\text { Santhica } \\
27\end{array}$ & Ivory & Mean \\
\hline$F M_{\text {whole plant }}$ & $\max \left[W P_{\max }=\right.$ Output $\left.\max / W_{\text {input }} \min \right]$ & 6.36 & 10.65 & 8.32 \\
\hline$F M_{\text {whole plant }}$ & $\min \left[W P_{\min }=\right.$ Output $\left.\min / W_{\text {input }} \max \right]$ & 0.99 & 2.31 & 1.49 \\
\hline$D M_{\text {whole plant }}$ & $\max \left[W P_{\max }=\right.$ Output $\left.\max / W_{\text {input }} \min \right]$ & 4.41 & 7.70 & 5.91 \\
\hline$D M_{\text {whole plant }}$ & $\min \left[W P_{\min }=\right.$ Output $\left.\min / W_{\text {input }} \max \right]$ & 0.69 & 1.74 & 1.09 \\
\hline$F M_{\text {bast }}$ & $\max \left[W P_{\max }=\right.$ Output $\left.\max / W_{\text {input }} \min \right]$ & 1.62 & 2.72 & 2.12 \\
\hline$F M_{\text {bast }}$ & $\min \left[W P_{\min }=\right.$ Output $\left.\min / W_{\text {input }} \max \right]$ & 0.25 & 0.61 & 0.39 \\
\hline$D M_{\text {bast }}$ & $\max \left[W P_{\max }=\right.$ Output $\left.\max / W_{\text {input }} \min \right]$ & 0.61 & 1.10 & 0.83 \\
\hline$D M_{\text {bast }}$ & $\min \left[W P_{\min }=\right.$ Output $\left.\min / W_{\text {input }} \max \right]$ & 0.12 & 0.31 & 0.19 \\
\hline
\end{tabular}

\section{Conclusions}

The problems associated with water deficit stress necessitate further investigations into the possibility of improving water use productivity in farming. To reach the goal of a reduction in water consumption or an increase in water productivity in agricultural production, firstly, causes of the high water use need to be identified. A consideration of the field scale and the farm scale can show farmers directly and more accurately where, when, and how many water resources were used and how optimizing of water use in agriculture could be achieved [31]. Evaporation of intercepted water was determined for plants of two hemp cultivars in a semi-dry cropping area in Brandenburg, Germany for the first time in this study. On average, it appeared to be high but was within the bandwidth for other crops grown under similar climatic conditions. For hemp, the evaporation of intercepted water cannot be neglected in the decision making for e.g., the assessment of water fluxes, because of its close relationships with precipitation and throughfall. The evaporation of intercepted water and the transpiration increased with $L A I$, which increased through the developmental stages. For throughfall and evaporation from intercepted water, no significant difference was found between plants of the two cultivars. The influence on the water productivity of the interception loss and reduced water reaching the soil within two hemp cultivars was smaller than assumed due to an existing unlimited water supply of groundwater located at $10 \mathrm{~m}$ depth at the research site. 
Future research is required to be able to build up a database of water-related indicators from farms using different management practices (including different crop cultivars) for specific regions. The evaluation of differences in water productivity between different farm systems can be achieved through this. The results presented here are particularly relevant for the respective climate of the year 2018 and for low loamy sand SL2 in the year 2018.

Due to the large uncertainties in this study, the bandwidths of the water productivity, calculated including measurement and modeling errors, were large. Further research is required to identify and overcome the influences of the various sources of uncertainty, especially the detailed analysis of throughfall and the modeling of transpiration. Optimization of calculation of cultivar-specific water productivity can, at best, be done by reducing the uncertainty resulting from throughfall measurements.

The results furthermore show that even with a precise examination of water productivity, a high bandwidth of local values is revealed on different cultivars and fields. Generic WP values for fiber crops, food crops, and feed crops are not attainable.

Author Contributions: Conceptualization, K.D. and H.-J.G.; methodology, K.D. and W.B.H.; software, K.D.; validation, I.F., W.B.H., H.-J.G. and K.D.; formal analysis, I.F.; investigation, I.F.; writing-original draft preparation, K.D.; writing-review and editing, I.F., W.B.H., H.-J.G. supervision, K.D. and H.-J.G.; project administration, H.-J.G. All authors have read and agreed to the published version of the manuscript.

Funding: This research received no external funding.

Acknowledgments: This study would not have been possible without the diligent work of Marcus Fischer, Uwe Hunstock, Leonie Jost and Benjamin Trost, for which we are very grateful. The authors also thank Linda Golding for checking the quality of the English language.

Conflicts of Interest: The authors declare no conflict of interest.

\section{Appendix A}

Table A1. Soil properties $(n=7)$ of the research site \pm standard deviations. Given are the volumetric soil water content $(V W C)$ at specific soil water potentials $(\mathrm{MPa})$ or $p F$-values, i.e., the decimal logarithm of the soil water potential, and the calculated gravimetric soil water storage (SWS) in $30 \mathrm{~cm}$ depth extrapolated over a depth of $2 \mathrm{~m}$.

\begin{tabular}{|c|c|c|}
\hline Parameter & $V W C[\%]$ & SWS 0-2 m [mm] \\
\hline $\begin{array}{l}\text { permanent wilting point (soil water content at } \\
\text { pF } 4.2 \text { i.e., } \Psi \text { soil }=-1.6 \mathrm{MPa})\end{array}$ & $8.2 \pm 0.5$ & 236 \\
\hline $\begin{array}{c}\text { field capacity (soil water content at } p F 1.8 \\
\text { i.e., } \Psi \text { soil }=-0.01 \mathrm{MPa} \text { ) }\end{array}$ & $26.5 \pm 0.7$ & 763 \\
\hline water retention capacity ( $p F 1.8-p F 4.2)$ & $18.3 \pm 1.0$ & 527 \\
\hline
\end{tabular}

Table A2. Relevant average climate parameters near the research site “DWD_03987_Potsdam" of the German Weather Service (DWD).

\begin{tabular}{ccccc}
\hline & MAP & MPV & MAT & WAT \\
\hline & {$\left[\mathrm{mm} \mathrm{a}^{-1}\right]$} & {$\left[\mathrm{mm} \mathrm{period}^{-1}\right]$} & {$\left[{ }^{\circ} \mathrm{C}\right]$} & {$\left[\mathrm{m} \mathrm{s}^{-1}\right]$} \\
mean ( \pm standard deviation) & $579( \pm 108)$ & $284( \pm 81)$ & $9.7( \pm 0.7)$ & $4.3( \pm 0.4)$ \\
2018 & 346 & 128 & 11.3 & 4.1 \\
\hline
\end{tabular}

$M A P$ : Long-term mean annual precipitation and annual precipitation in the individual experimental years. $M P V$ : Long-term mean precipitation and precipitation in the experimental year in the period May to September. MAT: Long-term mean annual air temperature $(2 \mathrm{~m})$ and annual mean air temperature in the experimental year. WAT: Long-term mean annual wind speed. 
Table A3. Summary of statistics of the comparison between measured and modeled mean daily transpiration of both cultivars, either modeled with unlimited water supply $(+)$ or limited water supply

$(-)$. Colors denote the goodness of fit of the model application red: lower quality, green: higher quality.

\begin{tabular}{|c|c|c|c|c|c|}
\hline \multicolumn{2}{|c|}{ Model Evaluation Statistics } & 'Santhica'- & 'Santhica'+ & 'Ivory'- & 'Ivory'+ \\
\hline \multirow{4}{*}{$\begin{array}{l}\text { Standard } \\
\text { regression }\end{array}$} & Slope & 1.5 & 0.61 & 1.24 & 1.00 \\
\hline & y-intercept & 2.68 & 2.12 & 1.05 & -0.38 \\
\hline & $\begin{array}{l}\text { Pearson's correlation } \\
\text { coefficient }(r)\end{array}$ & 0.88 & 0.80 & 0.92 & 0.90 \\
\hline & $\begin{array}{l}\text { Coefficient of } \\
\text { determination }\left(R^{2}\right)\end{array}$ & 0.77 & 0.63 & 0.84 & 0.81 \\
\hline \multirow[t]{2}{*}{ Dimen-sionless } & $\begin{array}{l}\text { Nash-Sutcliffe } \\
\text { efficiency (NSE) }\end{array}$ & -4.61 & 0.63 & -0.01 & 0.74 \\
\hline & $\begin{array}{l}\text { Logarithmic } \\
\text { transformed NSE } \\
\left(N S E_{\log }\right)\end{array}$ & -0.26 & 0.63 & 0.15 & 0.56 \\
\hline \multirow{3}{*}{ Error index } & $\begin{array}{l}\text { Root mean square } \\
\text { error }(R M S E)\end{array}$ & 4.11 & 2.34 & 1.89 & 1.17 \\
\hline & Percent bias (PBIAS) & 63.54 & -4.39 & 43.12 & -10.76 \\
\hline & Standard error $\left(S E_{\mathrm{T}}\right)$ & 0.38 & 0.45 & 0.31 & 0.31 \\
\hline
\end{tabular}

Table A4. Measurement and modeling uncertainties according to [43] for the two cultivars. Given are incident precipitation $(P)$, throughfall $(T F)$; transpiration $(T)$ and yield $(Y) ; C V=$ Coefficient of variation; $\mathrm{SD}=$ standard deviation of the differences; SE: standard error.

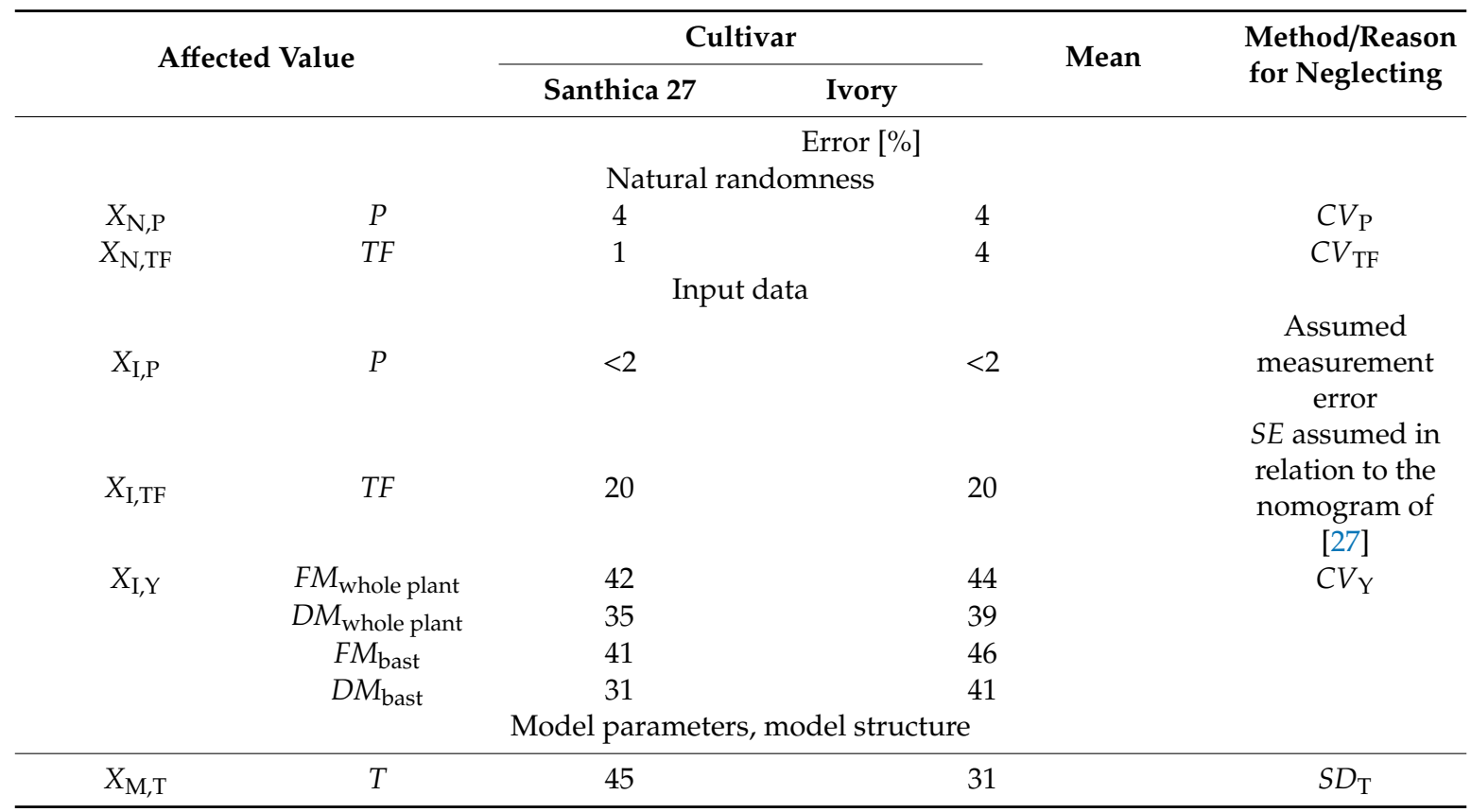


Table A5. Minimum and maximum values of $W_{\text {input }}$ and Output.

\begin{tabular}{|c|c|c|c|c|c|}
\hline & & & Santhica 27 & Ivory & Mean \\
\hline \multirow[t]{3}{*}{$W_{\text {input }}$} & $T_{\text {crop }+ \text { fallow }}+W_{\text {irri }}$ & $\mathrm{m}^{3} \mathrm{~m}^{-2}$ & & & \\
\hline & & Max & 1.01 & 0.61 & 0.81 \\
\hline & & Min & 0.39 & 0.33 & 0.36 \\
\hline \multirow[t]{3}{*}{ Output } & $F M_{\text {whole plant }}$ & $\mathrm{kg} \mathrm{m}-^{2}$ & & & \\
\hline & & Max & 2.48 & 3.49 & 2.99 \\
\hline & & Min & 1.00 & 1.42 & 1.21 \\
\hline \multirow[t]{3}{*}{ Output } & $D M_{\text {whole plant }}$ & $\mathrm{kg} \mathrm{m}^{-2}$ & & & \\
\hline & & $\max$ & 1.72 & 2.52 & 2.12 \\
\hline & & $\min$ & 0.70 & 1.06 & 0.88 \\
\hline \multirow[t]{3}{*}{ Output } & $F M_{\text {bast }}$ & $\mathrm{kg} \mathrm{m}^{-2}$ & & & \\
\hline & & Max & 0.63 & 0.89 & 0.76 \\
\hline & & Min & 0.26 & 0.38 & 0.32 \\
\hline \multirow[t]{3}{*}{ Output } & $D M_{\text {bast }}$ & $\mathrm{kg} \mathrm{m}^{-2}$ & & & \\
\hline & & Max & 0.24 & 0.36 & 0.30 \\
\hline & & Min & 0.12 & 0.19 & 0.16 \\
\hline
\end{tabular}

\section{References}

1. Amaducci, S.; Gusovius, H.-J. Hemp-cultivation, extraction and processing. In Industrial Applications of Natural Fibres: Structure, Properties and Technical Applications; John Wiley \& Sons, Inc.: Hoboken, NJ, USA, 2010; pp. 109-134. [CrossRef]

2. Fernando, A.L.; Duarte, M.P.; Vatsanidou, A.; Alexopoulou, E. Environmental aspects of fiber crops cultivation and use. Ind. Crop. Prod. 2015, 68, 105-115. [CrossRef]

3. Tang, K.; Struik, P.C.; Amaducci, S.; Stomph, T.-J.; Yin, X. Hemp (Cannabis sativa L.) leaf photosynthesis in relation to nitrogen content and temperature: Implications for hemp as a bio-economically sustainable crop. GCB Bioenergy 2017, 9, 1573-1587. [CrossRef]

4. Herer, J.; Bröckers, M. Die Wiederentdeckung der Nutzpflanze Hanf, Cannabis Marihuana: Mit einer Kurzstudie von Katalyse-Institut für Angewandte Umweltforschung eV; Zweitausendeins: Frankfurt am Main, Germany, 1994; ISBN 3861500590.

5. Bócsa, I.; Karus, M.; Lohmeyer, D. Der Hanfanbau: Botanik, Sorten, Anbau und Ernte, Märkte und Produktlinien; Landwirtschaftsverlag: Münster-Hiltrup, Germany, 2000.

6. Gedik, G.; Avinc, O. Hemp Fiber as a Sustainable Raw Material Source for Textile Industry: Can We Use Its Potential for More Eco-Friendly Production? In Sustainability in the Textile and Apparel Industries. Sustainable Textiles: Production, Processing, Manufacturing E Chemistry; Muthu, S., Gardetti, M., Eds.; Springer: Cham, Switzerland, 2020.

7. Barth, M.; Carus, M. Carbon Footprint and Sustainability of Different Natural Fibres for Biocomposites and Insulation Material; Nova-Institute: Hürth, Germany, 2015; Available online: http://news.bio-based.eu/media/2015/04/ 15-04-20_PR_Carbon-Footprint-of-Natural-Fibres_nova.pdf (accessed on 29 January 2020).

8. Cherrett, N.; Barrett, J.; Clemett, A.; Chadwick, M.; Chadwick, M.J. Ecological Footprint and Water Analysis of Cotton, Hemp and Polyester; Stockholm Environmental Institute: Stockholm, Sweden, 2005; Available online: https://mediamanager.sei.org/documents/Publications/SEI-ReportEcologicalFootprintAndWaterAnalysisOfCottonHempAndPolyester-2005.pdf (accessed on 27 March 2020).

9. Struik, P.; Amaducci, S.; Bullard, M.; Stutterheim, N.; Venturi, G.; Cromack, H. Agronomy of fibre hemp (Cannabis sativa L.) in Europe. Ind. Crop. Prod. 2000, 11, 107-118. [CrossRef]

10. Tang, K.; Struik, P.; Yin, X.; Thouminot, C.; Bjelková, M.; Stramkale, V.; Amaducci, S. Comparing hemp (Cannabis sativa L.) cultivars for dual-purpose production under contrasting environments. Ind. Crop. Prod. 2016, 87, 33-44. [CrossRef]

11. Tang, K.; Struik, P.; Yin, X.; Calzolari, D.; Musio, S.; Thouminot, C.; Bjelková, M.; Stramkale, V.; Magagnini, G.; Amaducci, S. A comprehensive study of planting density and nitrogen fertilization effect on dual-purpose hemp (Cannabis sativa L.) cultivation. Ind. Crop. Prod. 2017, 107, 427-438. [CrossRef]

12. Bócsa, I.; Karus, M. The Cultivation of Hemp: Botany, Varieties, Cultivation and Harvesting; Hemptech: Sebastopol, CA, USA, 1998; ISBN 1886874034. 
13. Bouloc, P.; van der Werf, H.M.G. The role of hemp in sustainable development. In Hemp: Industrial Production and Uses; Bouloc, P., Allegret, S., Arnaud, L., Eds.; CABI eBook: Wallingford, Oxfordshire, UK, 2013; pp. 278-289. [CrossRef]

14. Tang, K.; Fracasso, A.; Struik, P.C.; Yin, X.; Amaducci, S. Water- and nitrogen-use efficiencies of hemp (Cannabis sativa L.) based on whole-canopy measurements and modeling. Front. Plant Sci. 2018, 9, 951. [CrossRef]

15. Averink, J. Global Water Footprint of Industrial Hemp Textile; University of Twente: Enschede, The Netherlands, 2015; Available online: https://essay.utwente.nl/68219/1/Averink\%2C\%20J.\%200198501\%20openbaar.pdf (accessed on 27 March 2020).

16. Molden, D. Accounting for Water Use and Productivity; No. 42; IWMI: Colombo, Sri Lanka, 1997; Available online: http://www.iwmi.cgiar.org/Publications/SWIM_Papers/PDFs/SWIM01.PDF (accessed on 22 October 2020).

17. Kozak, J.A.; Ahuja, L.R.; Green, T.R.; Ma, L. Modelling crop canopy and residue rainfall interception effects on soil hydrological components for semi-arid agriculture. Hydrol. Process. Int. J. 2007, 21, 229-241. [CrossRef]

18. Drastig, K.; Quiñones, T.S.; Zare, M.; Dammer, K.-H.; Prochnow, A. Rainfall interception by winter rapeseed in Brandenburg (Germany) under various nitrogen fertilization treatments. Agric. For. Meteorol. 2019, 268, 308-317. [CrossRef]

19. Baroni, G.; Drastig, K.; Lichtenfeld, A.U.; Jost, L.; Claas, P. Assessment of irrigation scheduling systems in Germany: Survey of the users and comparative study. Irrig. Drain. 2019, 68, 520-530. [CrossRef]

20. LBGR, Landesamt für Bergbau, Geologie und Rohstoffe Brandenburg. 2019. Available online: http: //www.geo.brandenburg.de/boden (accessed on 23 July 2020).

21. Trost, B. Site Description Research Site Marquardt Fieldlab for Digital Agriculture, Leibniz-Institut fur Agrartechnik und Biookonomie e.V. (ATB). 2018. Available online: https://www.atb-potsdam.de/en/ institute/about-us/research-infrastructure/research-sites/equipment-and-site---description.html (accessed on 27 March 2020).

22. Herppich, W.; Gusovius, H.; Flemming, I.; Drastig, K. Effects of drought and heat on photosynthetic performance, water use and yield of two important fibre hemp cultivars at a poor-soil site in Brandenburg (Germany). Agronomy 2020, 10, 1361. Available online: https://www.mdpi.com/2073-4395/10/9/1361 (accessed on 22 October 2020). [CrossRef]

23. Solomon, R.W. Free and open source software for the manipulation of digital images. Am. J. Roentgenol. 2009, 192, W330-W334. [CrossRef]

24. Köstner, B.; Surke, M.; Bernhofer, C. Klimadiagnose der Region Berlin/Barnim/Uckermark/Uecker-Randow für den Zeitraum 1951 bis 2006. 2007. Available online: https://www.researchgate.net/publication/44175675_ Klimadiagnose_der_Region_Berlin_Barnim_Uckermark_Uecker-Randow_fur_den_Zeitraum_1951_bis_ 2006 (accessed on 22 October 2020).

25. Von Caemmerer, S.; Farquhar, G.D. Some relationships between the biochemistry of photosynthesis and the gas exchange of leaves. Planta 1981, 153, 376-387. [CrossRef] [PubMed]

26. Matyssek, R.; Herppich, W.B. Physikalische Grundlagen von Transpiration, $\mathrm{CO}_{2}-\mathrm{Aufnahme}$, Gasleitfähigkeiten und deren Bestimmungen. In Experimentelle Pflanzenökologie. Springer Reference Naturwissenschaften; Springer: Berlin/Heidelberg, Germany, 2017; pp. 1-30. [CrossRef]

27. Lloyd, C. Spatial variability of throughfall and stemflow measurements in Amazonian rainforest. Agric. For. Meteorol. 1988, 42, 63-73. [CrossRef]

28. Drastig, K.; Prochnow, A.; Kraatz, S.; Libra, J.; Krauß, M.; Döring, K.; Müller, D.; Hunstock, U. Modeling the Water Demand on Farms. 2012. Available online: https://oar.tib.eu/jspui/bitstream/123456789/701/1/adgeo32-9-2012.pdf (accessed on 22 October 2020).

29. Allen, R.; Pereira, L.; Raes, D.; Smith, M. Crop evapotranspiration-Guidelines for computing crop water requirements. In FAO Irrigation and Drainage Paper 56; FAO-Food and Agriculture Organization of the United Nations: Rome, Italy, 1998; 297p.

30. Kutschera, L.; Lichtenegger, E.; Sobotik, M. Wurzelatlas der Kulturpflanzen Gemäßigter Gebiete mit Arten des Feldgemüsebaues; DLG-Verlag: Frankfurt am Main, Germany, 2009; ISBN 978-3-7690-0851-7s.

31. Prochnow, A.; Drastig, K.; Klauss, H.; Berg, W. Water use indicators at farm scale: Methodology and case study. Food Energy Secur. 2012, 1, 29-46. [CrossRef] 
32. Doering, K.; Kraatz, S.; Prochnow, A.; Drastig, K. Indirect water demand of dairy farm buildings. Agric. Eng. Inter. CIGR J. 2013, 15, 16-22. Available online: https://cigrjournal.org/index.php/Ejounral/article/view/2726/ 1790 (accessed on 22 October 2020).

33. Maidment, D.R. Handbook of Hydrology; McGraw-Hill: New York, NY, USA, 1993; Volume 9780070, ISBN 9780070397323.

34. Moriasi, D.N.; Arnold, J.G.; Van Liew, M.W.; Bingner, R.L.; Harmel, R.D.; Veith, T.L. Model evaluation guidelines for systematic quantification of accuracy in watershed simulations. Trans. ASABE 2007, 50, 885-900. [CrossRef]

35. Ellis, J.; Kebreab, E.; Odongo, N.; McBride, B.; Okine, E.; France, J. Prediction of methane production from dairy and beef cattle. J. Dairy Sci. 2007, 90, 3456-3466. [CrossRef]

36. Tedeschi, L.O. Assessment of the adequacy of mathematical models. Agric. Syst. 2006, 89, 225-247. [CrossRef]

37. Michelson, D.B. Systematic correction of precipitation gauge observations using analyzed meteorological variables. J. Hydrol. 2004, 290, 161-177. [CrossRef]

38. Amaducci, S.; Amaducci, M.T.; Benati, R.; Venturi, G. Crop yield and quality parameters of four annual fibre crops (hemp, kenaf, maize and sorghum) in the North of Italy. Ind. Crop. Prod. 2000, 11, 179-186. [CrossRef]

39. Willmott, C.J. On the validation of models. Phys. Geogr. 1981, 2, 184-194. [CrossRef]

40. Santhi, C.; Arnold, J.G.; Williams, J.R.; Dugas, W.A.; Srinivasan, R.; Hauck, L.M. Validation of the SWAT model on a large river basin with point and nonpoint sources 1. JAWRA J. Am. Water Resour. Assoc. 2001, 37, 1169-1188. [CrossRef]

41. Van Liew, M.; Arnold, J.; Garbrecht, J. Hydrologic simulation on agricultural watersheds: Choosing between two models. Trans. ASAE 2003, 46, 1539-1551. [CrossRef]

42. Gupta, H.V.; Sorooshian, S.; Yapo, P.O. Status of automatic calibration for hydrologic models: Comparison with multilevel expert calibration. J. Hydrol. Eng. 1999, 4, 135-143. [CrossRef]

43. Melching, C.S. Reliability estimation. In Computer Models of Watershed Hydrology; Water Resources Publications: Highlands Ranch, CO, USA, 1995; Chapter 3.

44. FAOSTAT. Food and Agriculture Organization of the United Nations; Statistics Division; FAO: Rome, Italy, 2015; Available online: http://faostat3.fao.org/download/Q/QC/E (accessed on 23 July 2020).

45. Perović, D.; Crawley, B.; Hume, I.; Hoogers, R.; Sun, D.; Uddinie, J.; Regan, P. Benchmarking Water Productivity of Australian Irrigated Cotton. Primefact 1705; NSW Department of Primary Industries: State of New South Wales, Parramatta NSW, Australia, 2019. Available online: https://www.dpi.nsw.gov.au/agriculture/irrigation/irrigation/irrigation-primefacts/ benchmarking-water-productivity-of-australian-cotton-primefact (accessed on 27 March 2020).

46. Shareef, M.; Gui, D.; Zeng, F.; Waqas, M.; Zhang, B.; Iqbal, H. Water productivity, growth, and physiological assessment of deficit irrigated cotton on hyperarid desert-oases in northwest China. Agric. Water Manag. 2018, 206, 1-10. [CrossRef]

47. Neuer, H.; Prieger, E.; Sengbusch, R.V. Hanfzüchtung. Der Züchter 1946, 17, 33-39. [CrossRef]

Publisher's Note: MDPI stays neutral with regard to jurisdictional claims in published maps and institutional affiliations.

(C) 2020 by the authors. Licensee MDPI, Basel, Switzerland. This article is an open access article distributed under the terms and conditions of the Creative Commons Attribution (CC BY) license (http://creativecommons.org/licenses/by/4.0/). 